\title{
PERLINDUNGAN HUKUM TERHADAP KEPENTINGAN DEBITUR DAN KREDITUR DALAM PERJANJIAN KREDIT PT. BANK PEMBANGUNAN DAERAH X
}

\author{
GAMAR
}

gamar.aljufri@gmail.com

\begin{abstract}
Abstrak
Dalam proses pemberian kredit, bank menggunakan dua bentuk perjanjian kredit yaitu : perjanjian kredit baku (di bawah tangan) dan perjanjian kredit akta notaris. Tingkat keabsahan perjanjian kredit di bawah tangan sudah lama diperdebatkan, karena dinilai melanggar asas kebebasan berkontrak, Undang-Undang Perlindungan Konsumen dan Peraturan Otoritas Jasa Keuangan. Sedangkan untuk perjanjian kredit dengan akta notaris juga tidak terlepas dari konsep-konsep baku yang dirancang sendiri oleh bank. Penelitian ini dilakukan terhadap perjanjian kredit pada Bank Pembangunan Daerah yang membuka cabang di Ibukota Jakarta (BPD X). Permasalahan dalam tesis ini mengenai perlindungan hukum dari perjanjian kredit (baku dan notariil) serta peran notaris dalam pembuatan akta perjanjian kredit dan perlindungan hukum terhadap kepentingan hak-hak yang seimbang antara debitur dan kreditur terkait perjanjian kredit (baku dan notariil) pada BPD X. Untuk menjawab permasalahan itu digunakan metode penelitian yuridis normatif yang didukung dengan wawancara sehingga didapat kesimpulan dari kedua bentuk perjanjian kredit (baku dan notariil) pada BPD X belum memberikan hak yang seimbang antara bank dan nasabah debitur, karena kepentingan bank lebih diutamakan ketimbang nasabah debitur. Terkait peran notaris dalam pembuatan akta perjanjian kredit praktiknya lebih banyak didominasi oleh kepentingan bank. Seorang notaris seharusnya berperan netral, adil dan tidak memihak sesuai ketentuan Pasal 16 UUJN dan Kode Etik Notaris.
\end{abstract}

Kata Kunci: Perlindungan Hukum, Perjanjian Kredit (Baku dan Notariil).

\begin{abstract}
In the process of granting credit, banks use two forms of credit agreements, namely: standard credit agreement (under hand) and notary deed credit agreement. The level of validity of the underhanded credit agreement has long been debated, because it is considered to violate the principle of freedom of contract, the Consumer Protection Act and the Financial Services Authority Regulation. As for the credit agreement with a notary deed is also inseparable from the standard concepts that are designed by the bank. This research was conducted on credit agreements with Regional Development Banks that opened branches in the Capital City of Jakarta (BPD X). The problems in this thesis are about legal protection from credit agreements (standard and notarial) and the role of notaries in making credit agreement deeds and legal protection against the interests of balanced rights between debtors and creditors related to credit agreements (standard and notarial) on BPD X. For answering the problem used normative juridical research method supported by interviews so that conclusions from both forms of credit agreements (standard and notarial) on BPD X have not given balanced rights between banks and debtor customers, because the interests of banks are preferred over debtor customers. Regarding the role of the notary in making the loan agreement, the practice is more dominated by the interests of the bank. Notary should
\end{abstract}


play a neutral, fair and impartial role in accordance with the provisions of Article 16 of the UUJN and the Notary Code of Ethics.

Keywords: Legal Protection, Credit Agreement (Baku and Notarial).

\section{PENDAHULUAN}

Kredit merupakan elemen yang penting di dalam variabel yang mempengaruhi pertumbuhan ekonomi dan sebagai penggerak roda perekonomian suatu daerah. Seiring meningkatnya pembangunan ekonomi, lembaga perbankan telah membantu kebutuhan pemenuhan dana dalam pembangunan perekonomian melalui kredit perbankan, yaitu berupa perjanjian kredit antara kreditur sebagai pemberi pinjaman dan debitur sebagai penerima pinjaman.

Bank sebelum melakukan penyaluran kredit terlebih dahulu mengadakan perjanjian kredit dengan calon debiturnya. Perjanjian kredit dapat dilakukan dengan 2 (dua) cara yaitu secara di bawah tangan dan akta notariil. Pelaksanaan dalam perjanjian kredit perbankan hampir keseluruhan menggunakan bentuk perjanjian baku (standard contract) atau klausula baku. Alasan digunakannya perjanjian baku, karena keadaan sosial ekonomi. Fenomena perjanjian kredit dengan klausula bakunya, menimbulkan persoalan hukum baru dengan diberlakukannya Undang-Undang Nomor 8 Tahun 1999 tentang Perlindungan Konsumen (selanjutnya disingkat menjadi UUPK), pada Pasal 1 butir 10 mengatur tentang pengertian Klausula Baku. "Klausula baku adalah setiap aturan atau ketentuan dan syarat-syarat yang telah dipersiapkan dan ditetapkan terlebih dahulu secara sepihak oleh pelaku usaha, yang dituangkan dalam suatu dokumen dan/atau perjanjian yang mengikat dan wajib dipenuhi oleh konsumen." Selain itu terdapat pengaturan mengenai Perjanjian Baku Tahun 2014 khususnya bagi Pelaku Usaha Jasa Keuangan (PUJK) yang diatur di dalam Surat Edaran Otoritas Jasa Keuangan Nomor 13/SEOJK.07/2014 tentang Perjanjian Baku, yang mengatur mengenai ketentuan petunjuk pelaksanaan untuk menyesuaikan klausula dalam perjanjian baku.

Jasa notaris, sebagai pejabat umum yang membuat akta otentik sangat dibutuhkan dalam kegiatan usaha perbankan, salah satunya adalah dalam pembuatan akta perjanjian kedit perbankan yang melibatkan nasabah debitur dan bank sebagai kreditur, guna menjamin kebenaran dari isi yang dituangkan dalam perjanjian kredit perbankan tersebut, supaya secara publik kebenarannya tidak diragukan lagi. Peran notaris dalam pembuatan akta

\footnotetext{
${ }^{1}$ Indonesia (a), Undang-Undang tentang Perlindungan Konsumen, UU No 8/99, Pasal 1 butir 10.
} 
perjanjian kredit perbankan sangat penting, notaris sebagai pejabat publik dituntut untuk bersikap profesional yang salah satunya adalah menjembatani kepentingan kreditur dan debitur dalam pembuatan akta perjanjian kredit. Akan tetapi kenyataanya sikap profesionalisme tersebut berhadapan dengan tuntutan dunia perbankan, yaitu efesiensi prosedur perbankan, dan keamanan dalam pemberian kredit, sehingga dalam praktik lembaga perbankan cenderung menggunakan perjanjian baku dalam perjanjian kreditnya. ${ }^{2}$

Pada sisi lain, dilihat bagaimana seharusnya peran notaris dalam pembuatan aktaakta perjanjian kredit dan akta-akta pendukungnya dalam rangka pemberian kredit kepada nasabah debitur. Dapat dikatakan sebagian besar notaris lebih banyak memperhatikan kepentingan bank dari pada kepentingan nasabah debitur, sebagaimana terlihat dalam klausul-klausul akta perjanjian kredit. Apabila ditinjau dari Undang-Undang Nomor 2 Tahun 2014 tentang Perubahan Atas Undang-Undang Nomor 30 Tahun 2004 tentang Jabatan Notaris (selanjutnya disingkat UUJN), pada Pasal 16 ayat 1 (a) "seharusnya seorang notaris dalam menjalankan jabatannya wajib bertindak amanah, jujur, seksama, mandiri, tidak berpihak, dan menjaga kepentingan pihak yang terkait dalam perbuatan hukum." ${ }^{\text {’3 }}$. Sikap keberpihakan notaris kepada bank tampak melalui serangkaian intervensi bank kepada notaris seperti memuat klausul-klausul dari model perjanjian kredit bank yang bersangkutan yang pada akhirnya menguntungkan kepentingan bank dan sisi lain merugikan kepentingan nasabah sebagai debitur. ${ }^{4}$

Terkait hal ini penulis tertarik untuk melakukan penelitian dengan objek studi mengenai beberapa jenis Perjanjian Kredit pada PT. Bank Pembangunan Daerah X (selanjutnya disingkat BPD X) yang berkedudukan di Jakarta, alasan penulis untuk melakukan kajian dengan objek penelitian ini karena BPD X merupakan salah satu dari bank daerah yang membuka kantor cabang di Ibukota Jakarta, dengan hal ini dikaitkan dengan latar belakang nasabah debitur yang mayoritas dari Ibukota dengan pendidikan dan analisis yang lebih baik apabila dibanding masyarakat di daerah. Dalam penulisan ini dikhususkan pada upaya dari bank daerah yang melakukan perlindungan hukum terhadap nasabah debitur nya melalui perjanjian kredit dan bagaimana upaya dari bank tersebut untuk melindungi kepentinganya sebagai kreditur. Sehingga, permasalahan yang diangkat dalam penulisan ini adalah bagaimana bentuk perlindungan hukum dari perjanjian kredit (baku/standar dan

\footnotetext{
${ }^{2}$ Mariah Kamelia dan Anis Mashdurohatun, Peran Notaris Dalam Pembuatan Akta Perjanjian Kredit Dalam Perspektif Hukum Positif dan Hukum Islam, Jurnal Akta Magister Kenotariatan UNISSULA, vol 4, 2017.

${ }^{3}$ Indonesia (b), Undang-UndangTentang Jabatan Notaris, UU No 2/2014, Pasal 16 ayat 1 (a).

${ }^{4}$ Mariah Kamelia dan Anis Mashdurohatun, Op.cit.
} 
notariil) serta peran notaris dalam pembuatan akta perjanjian kredit dan bagaimana bentuk perlindungan hukum terhadap kepentingan hak-hak yang seimbang antara debitur dan kreditur terkait perjanjian kredit (baku/standar dan notariil) pada PT. Bank Pembangunan Daerah X.

Untuk menjawab permasalahan di atas digunakan metode pendekatan hukum yuridis normatif. Penelitian dengan pendekatan hukum yuridis normatif yaitu penelitian terhadap asas-asas hukum yang dilakukan terhadap norma-norma hukum dalam masyarakat yaitu yang merupakan patokan untuk bertingkah laku. Penelitian demikian dapat dilakukan terhadap bahan hukum primer dan bahan hukum sekunder serta bahan hukum tersier yang mengandung norma-norma hukum. Tidak semua pasal dalam suatu perundang-undangan mengandung norma hukum, ada pasal-pasal yang hanya memberikan batasan atau definisi saja seumpamanya yang biasanya ditentukan pada bab ketentuan-ketentuan umum dalam suatu perundang-undangan. ${ }^{5}$ Masalah dalam penelitian ini telah terjadi dalam praktik dunia perbankan, namun hingga saat ini belum dapat diselesaikan apabila dikaitakan dengan peraturan perundang-undangan yang berlaku dan asas proporsionalitas dalam berkontrak.

Teori yang digunakan dalam penulisan ini adalah teori perlindungan hukum, sebagaimana diuraikan oleh Salmond bahwa "hukum bertujuan mengintegrasikan dan mengkoordinasikan berbagai kepentingan dalam masyarakat karena dalam suatu lalu lintas kepentingan, perlindungan terhadap kepentingan tertentu hanya dapat dilakukan dengan cara membatasi berbagai kepentingan di lain pihak". 6

Kepentingan hukum adalah mengurusi hak dan kepentingan manusia, sehingga hukum memiliki otoritas tertinggi untuk menentukan kepentingan manusia yang perlu diatur dan dilindungi. Perlindungan hukum harus melihat tahapan yakni perlindungan hukum lahir dari suatu ketentuan hukum dan segala peraturan hukum yang diberikan oleh masyarakat yang pada dasarnya merupakan kesepakatan masyarakat tersebut untuk mengatur hubungan perilaku antara anggota-anggota masyarakat dan antara perseorangan dengan pemerintah yang dianggap mewakili kepentingan masyarakat.

\footnotetext{
${ }^{5}$ Roni Hanitijo Soemitro, Metodologi Penelitian Hukum dan Jarimetri, (Jakarta : Ghalia Indonesia, 1998), hlm. 15.

${ }^{6}$ Satjipto Raharjo, Ilmu Hukum, (Bandung, PT. Citra Aditya Bakti, 2000). hlm 54
} 


\section{PEMBAHASAN}

\section{Perlindungan Hukum Dari Perjanjian Kredit (Baku/Standar dan Notariil) Serta Peran Notaris Dalam Pembuatan Akta Perjanjian Kredit}

Penulisan ini menemukan berbagai bentuk atau format perjanjian kredit yang dilakukan terhadap objek penelitian. Dalam praktiknya perjanjian kredit perbankan dilaksanakan dengan 2 (dua) macam format yaitu secara di bawah tangan maupun notariil. Untuk nominal kredit di atas 1 (satu) miliar rupiah wajib menggunakan akta perjanjian berbentuk notariil, sedangkan untuk nominal di bawah itu hanya menggunakan perjanjian yang dilakukan di bawah tangan dengan perjanjian yang bersifat baku/standar dari kreditur. Pembuatan perjanjian kredit notariil tidak lepas dari peran perbankan untuk menentukan poin-poin yang harus tercantum di dalam perjanjian kredit yang dibuat yang harus dipenuhi oleh notaris. $^{7}$

Dalam pemberian kredit oleh bank sangat diperlukan peran notaris sebagai pejabat umum yang berwenang membuat akta perjanjian pinjam meminjam uang antara debitur dengan pihak bank selaku kreditur. Selain membuat akta perjanjian kredit sebagai perjanjian pokoknya peran notaris dalam hubungan kerja dengan pihak perbankan untuk pengikatan agunan kredit. Dalam menyalurkan kredit pihak bank selalu mengedepankan prinsip kepercayaan dan kehati-hatian. Apabila bank telah memperoleh keyakinan atas kemampuan calon debitur untuk mengembalikan kredit yang disalurkan maka sebenarnya pihak bank tidak perlu meminta jaminan tambahan, akan tetapi pada praktiknya bank masih juga meminta adanya jaminan tambahan berupa hak kebendaan untuk lebih menambah keyakinan bank bahwa nantinya debitur akan mampu melunasi kreditnya tepat waktu dan apabila debitur kedepanya melakukan wanprestasi maka bank dapat melakukan eksekusi benda jaminan yang diserahkan oleh debitur untuk memperoleh pelunasan atas kredit yang disalurkan. Disinilah peran notaris sebagai pejabat umum yang dapat membuat akta-akta yang terkait dengan pengikatan agunan tersebut, seperti misalnya pembuatan Akta Jaminan Fidusia, SKMHT, APHT, Akta Cessie dan lain sebagainya yang nantinya akan dilanjutkan dengan pendaftaran pada lembaga-lembaga terkait seperti pada Kementerian Hukum dan HAM dan Badan Pertanahan Nasional (BPN) oleh PPAT. ${ }^{8}$ Dengan dibuatnya akta perjanjian kredit notariil dan akta pengikatan jaminan oleh notaris dalam penyaluran fasilitas kredit oleh bank tentu sangat memberikan jaminan kepastian hukum bagi pihak bank dan debitur ketika nantinya terjadi wanprestasi dari debitur sehingga menyebabkan kredit macet.

\footnotetext{
${ }^{7}$ Ibid.

${ }^{8}$ Putu Devi Yustisia, dkk., Kedudukan Hukum Grosse Akta Pengakuan Hutang Notariil Dalam Pemberian Kredit Perbankan, Jurnal Magister Kenotariatan Universitas Udayana, 2018.
} 


\section{Perlindungan Hukum Terhadap Kepentingan Hak-Hak Yang Seimbang Antara Debitur Dan Kreditur Terkait Perjanjian Kredit (Baku/Standar dan Notariil) Pada BPD X}

Dalam penulisan ini dilakukan penelitian terhadap 3 (tiga) jenis perjanjian kredit baik dalam format baku dan notariil terhadap perjanjian kredit kepemilikan rumah, investasi dan modal kerja. Berikut akan diuraikan format perjanjian kredit di bawah tangan yang disebut juga sebagai perjanjian standar dan perjanjian kredit notariil yang dibuat oleh notaris. Terkait perjanjian kredit yang dilakukan pada BPD X, dari 3 (tiga) jenis perjanjian kredit (KPR, Investasi, dan Modal Kerja), agar lebih mudah untuk dipahami mengenai adanya klausul yang menurut penulis dinilai melanggar ketentuan peraturan perundang-undangan, akan diuraikan dalam tabel yaitu sebagai berikut :

Tabel 1. Analisis Klausul Perjanjian Kredit KPR, Investasi dan Modal Kerja

\begin{tabular}{|c|c|c|}
\hline NO & KLAUSUL & ANALISIS \\
\hline 1 & $\begin{array}{l}\text { Pasal } 3 \text { ayat } 4 \text { Perjanjian KPR } \\
\text { Debitur setuju bahwa pihak bank berhak } \\
\text { mengubah suku bunga sebagaimana tercantum } \\
\text { dalam lampiran } 1 \text { perjanjian kredit dari waktu } \\
\text { ke waktu berdasarkan kebijaksanaan bank } \\
\text { dengan memperhatikan kondisi pasar } \\
\text { keuangan. Bank akan memberitahukan } \\
\text { perubahan ini melalui surat atau melalui } \\
\text { pengumuman pada kantor cabang bank dan } \\
\text { perubahan tersebut akan mulai berlaku bagi } \\
\text { pembayaran angsuran bulan berikutnya. }\end{array}$ & $\begin{array}{l}\text { Kata setuju dalam pasal tersebut } \\
\text { berarti debitur sepakat atau harus } \\
\text { menyetujui kehendak kreditur, } \\
\text { sedangkan persetujuan tersebut } \\
\text { bersifat semu atau fiktif, karena } \\
\text { kesepakatan itu pada dasarnya tidak } \\
\text { dibuat dan hanya merupakan } \\
\text { pemberitahuan dari bank. Jadi bukan } \\
\text { kesepakatan atas dasar konsensuil } \\
\text { sebagaimana layaknya dalam unsur- } \\
\text { unsur perjanjian. }\end{array}$ \\
\hline 2 & $\begin{array}{l}\text { Pasal } 4 \text { ayat } 3 \text { Perjanjian KPR } \\
\text { Bank tidak diwajibkan untuk mengirimkan } \\
\text { surat-surat tagihan kepada debitur, sehingga } \\
\text { dengan atau tanpa adanya surat tagihan } \\
\text { debitur harus tetap memenuhi pembayaran } \\
\text { angsuran sesuai jadwal yang ditentukan dalam } \\
\text { lampiran } 1 \text { perjanjian kredit. }\end{array}$ & $\begin{array}{l}\text { Surat tagihan menjadi penting untuk } \\
\text { selalu diberikan kepada debitur, } \\
\text { karena isinya yang tidak hanya } \\
\text { mencantumkan kewajiban nasabah } \\
\text { debitur khususnya dalam } \\
\text { pembayaran kredit, tetapi juga } \\
\text { mencantumkan hak nasabah debitur } \\
\text { dalam hal pembayaran seperti } \\
\text { pembayaran minimum bahkan } \\
\text { termasuk juga mengenai tingkat suku } \\
\text { bunga yang berlaku saat itu. Dengan } \\
\text { tidak wajibnya untuk memberikan } \\
\text { surat tagihan, maka berarti nasabah } \\
\text { sendiri yang harus aktif dalam } \\
\text { berhubungan dengan kreditur, } \\
\text { sedangkan bank hanya bersifat pasif. }\end{array}$ \\
\hline
\end{tabular}




\begin{tabular}{|c|c|c|}
\hline 3 & $\begin{array}{l}\text { Pasal } 5 \text { ayat } 1 \text { Perjanjian KPR } \\
\text { Pelunasan dipercepat tidak diperbolehkan, } \\
\text { namun apabila debitur bermaksud untuk } \\
\text { melunasi hutangnya kepada bank sebelum } \\
\text { berakhirnya jangka waktu kredit, maka } \\
\text { debitur harus mengajukan permohonan tertulis } \\
\text { kepada bank untuk mendapatkan } \\
\text { persetujuannya, dan wajib membayar biaya } \\
\text { penalty sebagaimana tercantum dalam } \\
\text { lampiran } 1 \text { perjanjian kredit, biaya mana dapat } \\
\text { diubah bank dari waktu ke waktu dengan } \\
\text { pemberitahuan kepada debitur. }\end{array}$ & $\begin{array}{l}\text { Menurut penulis klausul ini tidak adil } \\
\text { saat nasabah debitur telat membayar } \\
\text { angsuran, debitur dikenakan denda } \\
\text { akibat keterlambatan pembayaran, } \\
\text { saat debitur ingin melunasi dari } \\
\text { jadwal sebelumnya juga dikenakan } \\
\text { beban biaya penalty. }\end{array}$ \\
\hline 4 & $\begin{array}{l}\text { Pasal } 7 \text { ayat } 3 \text { Perjanjian KPR } \\
\text { Guna menjamin pembayaran pokok kredit, } \\
\text { bunga, denda dan pembayaran lainnya dalam } \\
\text { rangka pelunasan kredit, debitur harus } \\
\text { menyerahkan barang agunan dan } \\
\text { menyerahkan bukti-bukti kepemilikan agunan } \\
\text { yang asli kepada kreditur }\end{array}$ & $\begin{array}{l}\text { Sesuai ketentuan Pasal } 14 \text { ayat } 4 \text { UU } \\
\text { Nomor } 4 \text { Tahun } 1996 \text { tentang Hak } \\
\text { Tanggungan diatur mengenai } \\
\text { sertifikat asli dikembalikan kepada } \\
\text { debitur pasca pendaftaran hak } \\
\text { tanggungan di BPN, namun dalam } \\
\text { praktiknya sertifikat asli tanah dan } \\
\text { sertifikat hak tanggungan keduanya } \\
\text { tetap dipegang oleh kreditur guna } \\
\text { memudahkan proses eksekusi } \\
\text { jaminan debitur apabila kemudian } \\
\text { hari terjadinya wanprestasi. }\end{array}$ \\
\hline 5 & $\begin{array}{l}\text { Pasal 12 Perjanjian KPR } \\
\text { Kejadian kelalaian yang dilakukan oleh pihak } \\
\text { debitur. Apabila menyimpang dari jadwal } \\
\text { pembayaran kembali hutang yang ditentukan } \\
\text { dalam perjanjian kredit, bank berhak dengan } \\
\text { pemberitahuan kepada debitur untuk } \\
\text { menuntut/menagih pembayaran seluruh } \\
\text { hutang yang terhutang dengan seketika dan } \\
\text { sekaligus, dan debitur wajib membayar hutang } \\
\text { sekaligus tanpa diperlukan somasi/teguran } \\
\text { lebih lanjut, apabila debitur alpa membayar } \\
\text { seluruh hutang segera dan sekaligus, bank } \\
\text { berhak melaksanakan eksekusi atas barang } \\
\text { agunan, bilamana terjadi kelalaian yang } \\
\text { dilakukan oleh debitur. }\end{array}$ & $\begin{array}{l}\text { Terjadinya tindakan sepihak oleh } \\
\text { bank tanpa adanya somasi/teguran } \\
\text { kepada nasabah debitur akibat } \\
\text { kelalaian yang dilakukan, hal ini } \\
\text { menurut penulis tidak adil. Terkait } \\
\text { kelalaian yang dilakukan debitur jika } \\
\text { debitur lalai atau melakukan } \\
\text { wanprestasi pada saat pelunasan } \\
\text { kredit telah mencapai } 90 \% \text { atau } 95 \% \\
\text { dari total kredit yang diberikan, } \\
\text { apakah debitur harus melakukan } \\
\text { pengosongan, pada perjanjian kredit } \\
\text { dan ketentuan pokok perjanjian } \\
\text { kredit tidak memberikan batasan } \\
\text { waktu atau jumlah (kuantitas) } \\
\text { pelunasan kredit yang telah } \\
\text { dilakukan oleh debitur }\end{array}$ \\
\hline 6 & $\begin{array}{l}\text { Pasal } 12 \text { ayat } 1 \text { Perjanjian KPR } \\
\text { Segala sesuatu yang belum diatur dalam } \\
\text { perjanjian kredit ini akan diatur dalam surat- } \\
\text { menyurat berdasarkan kesepakatan bersama } \\
\text { antara bank dan debitur yang merupakan } \\
\text { bagian yang tidak terpisahkan dari perjanjian } \\
\text { kredit. }\end{array}$ & $\begin{array}{l}\text { Mengenai ketentuan tambahan yang } \\
\text { dilakukan di luar perjanjian kredit ini } \\
\text { termasuk pelanggaran yang diatur } \\
\text { pada Pasal } 22 \text { POJK.01/2013 yang } \\
\text { menyatakan "Pelaku Usaha Jasa } \\
\text { Keuangan dilarang menyatakan } \\
\text { bahwa konsumen tunduk pada } \\
\text { peraturan baru, tambahan, lanjutan } \\
\text { dan/atau perubahan yang dibuat oleh }\end{array}$ \\
\hline
\end{tabular}




\begin{tabular}{|c|c|c|}
\hline & & $\begin{array}{l}\text { Pelaku Jasa Keuangan dalam masa } \\
\text { konsumen memanfaatkan produk } \\
\text { dan/atau layanan yang dibelinya." }\end{array}$ \\
\hline 7 & $\begin{array}{l}\text { Pasal } 6 \text { ayat } 2 \text { Perjanjian Kredit Investasi } \\
\text { Perjanjian ini memberi kuasa dan wewenang } \\
\text { penuh kepada kreditur, kuasa mana adalah } \\
\text { kuasa mutlak tanpa syarat apapun dan tidak } \\
\text { dapat ditarik kembali oleh debitur dan oleh } \\
\text { karenanya kuasa ini tidak akan berakhir } \\
\text { karena sebab-sebab yang ditentukan oleh } \\
\text { Pasal } 1813 \text { KUHPerdata, untuk memotong, } \\
\text { mendebet, mengirimkan dana di dalam } \\
\text { rekening debitur (baik rekening pinjaman } \\
\text { maupun rekening simpanan) dan } \\
\text { menggunakan dana hasil pemotongan, } \\
\text { pendebetan dan pengiriman tersebut untuk } \\
\text { memenuhi kewajiban debitur }\end{array}$ & $\begin{array}{l}\text { Hal ini tentu melanggar ketentuan } \\
\text { yang tercantum dalam } \\
\text { SEOJK.07/2014 yang menyatakan } \\
\text { perjanjian baku dilarang memuat } \\
\text { pemberian kuasa dari konsumen } \\
\text { kepada PUJK, baik secara } \\
\text { langsung maupun tidak langsung, } \\
\text { untuk melakukan segala tindakan } \\
\text { sepihak, kecuali tindakan sepihak } \\
\text { tersebut dilakukan berdasarkan } \\
\text { peraturan perundang-undangan. }\end{array}$ \\
\hline 8 & $\begin{array}{l}\text { Pasal } 8 \text { ayat } 4 \text { Perjanjian Kredit Modal } \\
\text { Kerja (Notariil) } \\
\text { Biaya provisi kredit, biaya administrasi dan } \\
\text { supervisi wajib dibayar lunas oleh penerima } \\
\text { kredit setelah ditandatangani perjanjian kredit } \\
\text { dan tidak diperhitungkan dengan bunga bulan } \\
\text { pertama. Pembayaran tersebut tidak bisa } \\
\text { ditarik kembali sekalipun pada akhirnya kredit } \\
\text { tidak jadi dipergunakan }\end{array}$ & $\begin{array}{l}\text { Disini tercermin tidak adanya unsur } \\
\text { keadilan pada perjanjian kredit dan } \\
\text { hal ini bertentangan dengan UUPK. } \\
\text { Apabila perjanjian ini dibatalkan } \\
\text { oleh pihak penerima kredit klausul } \\
\text { ini masih dimungkinkan untuk } \\
\text { diterima, setidak-tidaknya ia sebagai } \\
\text { penalti atau denda atas komitmen } \\
\text { yang telah dibuat sebelumnya. Tetapi } \\
\text { hal ini menurut penulis tidak adil } \\
\text { apabila yang membatalkan perjanjian } \\
\text { kredit ini dilakukan oleh pihak bank } \\
\text { sementara seluruh biaya-biaya yang } \\
\text { telah dikeluarkan tidak dapat ditarik } \\
\text { kembali oleh calon debitur. }\end{array}$ \\
\hline
\end{tabular}

Sumber : diolah dari Perjanjian Kredit KPR, Investasi dan Modal Kerja BPD X.

Dari hasil penelitian yang dilakukan terhadap perjanjian kredit pada BPD X menunjukan bahwa sebagian besar bentuk perjanjian kredit (baku/standar) yang dibuat di bawah tangan maupun dalam akta notaris, terlihat tidak adanya keseimbangan. Artinya, ketentuan yang dimuat dalam klausul-klausul yang ada dalam perjanjian kredit hanya memperhatikan kepentingan pihak bank sebagai kreditur, jadi keadaanya cenderung menguntungkan bank dan sebaliknya membebankan banyak kewajiban kepada nasabah selaku debitur dan yang pada akhirnya merugikan debitur. 


\section{a. Perlindungan Terhadap Kepentingan Nasabah Debitur}

Di Indonesia terdapat beberapa aturan yang mengatur mengenai perlindungan nasabah sebagai konsumen dan sebagai pelaku usaha jasa keuangan yang diatur oleh Undang-Undang Nomor 8 Tahun 1999 tentang Perlindungan Konsumen, Peraturan Otoritas Jasa Keuangan Nomor : 1/POJK.07/2013 tentang Perlindungan Konsumen Sektor Jasa Keuangan, dan Surat Edaran Otoritas Jasa Keuangan Nomor 13/SEOJK.07/2014 tentang Perjanjian Baku. Ketiga peraturan tersebut memiliki kesamaan yang pada intinya melarang pelaku usaha dalam menawarkan produk barang/atau jasa untuk membuat atau mencantumkan klausula baku dalam setiap perjanjian yang dibuat.

Apabila dikaitkan dengan isi perjanjian kredit pada BPD X, dari hasil wawancara yang dilakukan terdapat pandangan yang sama antara notaris dan pejabat bank sehubungan dengan aturan yang terdapat pada Pasal 18 UUPK. Mengenai ketentuan pada Pasal 18 ayat 1 (a) UUPK yang menyatakan pengalihan tanggungjawab, sebagian besar narasumber mengatakan bahwa aturan mengenai pengalihan tanggungjawab yang dirumuskan dalam salah satu klausul perjanjian kredit itu sangat penting untuk keamanan bank, apabila klausul tersebut tidak ada, bank dapat dirugikan oleh debitur nakal yang melakukan perubahan anggaran dasar terutama pada perubahan pengurus (direksi), sedangkan perubahan itu belum menadapat pengesahan oleh Menteri Hukum dan Hak Asasi Manusia dan belum diumumkan dalam Berita Negara. Disinilah esensinya bank tidak bertanggungjawab jika terdapat masalah yang tidak diinginkan ini terjadi di kemudian hari, seperti debitur melakukan tindakan wanprestasi, tidak mau membayar kredit dan sebagainnya. ${ }^{9}$

Mengenai larangan klausula baku yang terdapat pada ketentuan Pasal 18 ayat 1 (g) UUPK yang menyatakan tunduknya konsumen pada peraturan baru yang dibuat oleh pelaku usaha. Dalam praktiknya terdapat klausul yang menyatakan tunduknya nasabah terhadap ketentuan baru yang dibuat oleh bank. Dari hasil wawancara yang dilakukan kepada pihak bank menyatakan bahwa hal tersebut akan dilakukan terlebih dahulu dengan pemberitahuan sebelumnya kepada nasabah debitur. ${ }^{10}$

Selanjutnya mengenai ketentuan pada Pasal 18 ayat 2 UUPK tentang larangan bagi pelaku usaha dalam hal ini pihak bank untuk membuat klausula baku yang bentuk dan isinya sulit dimengerti, menurut pandangan penulis pada prinsipnya terkait perjanjian kredit baku di bawah tangan dapat dipahami dari penulisannya namun dari bahasa yang

\footnotetext{
${ }^{9}$ Hasil wawancara penulis dengan narasumber (Notaris dan Pimpinan BPD X) pada November 2018.

${ }^{10}$ Ibid.
} 
digunakan terdapat beberapa penggunaan bahasa yang asing bagi masyarakat khusunya nasabah selaku debitur.

\section{b. Perlindungan Terhadap Kepentingan Kreditur}

Disisi lain terhadap pembuatan perjanjian kredit yang dibuat oleh pihak bank sebagai kreditur sebenarnya memiliki alasan untuk dibuatnya klausul-klausul yang ada dalam perjanjian tersebut. Dengan memberikan dana pinjaman kepada nasabah debitur pihak bank memiliki risiko yang cukup besar apabila suatu saat debitur melakukan wanprestasi terhadap apa yang telah diperjanjikan. Disini pihak bank memiliki kewenangan untuk membuat aturan berupa klausul yang bersifat baku tujuanya untuk melindungi kepentingan dirinya.

Menurut penulis terdapat beberapa alasan dari pihak bank membuat klausulklausul yang bersifat berat sebelah apabila ditinjau dari sisi debitur, alasan tersebut antara lain sebagai berikut :

a) Klausul mengenai penetapan besarnya bunga oleh pihak bank.

Pencantuman klausul tersebut berbunyi "bank berhak sewaktu-waktu untuk menetapkan besarnya suku bunga kredit yang harus dibayar oleh nasabah debitur dengan pemberitahuan. Mengenai klausul tersebut seharusnya tidak diartikan bank bersikap sewenang-wenang untuk menentukan besarnya suku bunga yang dibayar oleh debitur, namun pelaksanaanya tentunya disesuaikan dengan Suku Bunga Bank Indonesia (SBI), dengan demikian tidak akan terjadi kenaikan yang semata-mata ditentukan menurut versi bank sendiri.

b) Klausul bunga, provisi, dan denda keterlambatan pembayaran

Pencantuman klausula ini dalam praktik bisnis adalah hal yang wajar. Pengenaan bunga, provisi dan sanksi berupa denda apabila terjadi keterlambatan merupakan instrumen pengikat agar nasabah debitur menepati kewajiban kontraktualnya dengan sebaik-baiknya. Dengan dipenuhi kewajiban secara baik dan tepat waktu, tidak saja menguntungkan bank tetapi dapat dijadikan salah satu indikator keberhasilan bisnis debitur.

c) Klausul penggunaan dana

Pencantuman klausul ini ditentukan untuk mengevaluasi pemanfaatan dana kredit agar sesuai dengan peruntukannya, misal pemberian kredit modal kerja tidak dapat digunakan untuk keperluan konsumtif. Oleh karena itu, klausul ini selalu diikuti dengan klausul pengawasan terhadap pembukuan nasabah debitur untuk mendeteksi alur keluar masuk dana serta peruntukannya. Bahkan apabila terbukti terjadi penyimpangan penggunaan dana, maka bank akan menghentikan proses pencairan 
kredit selanjutnya, dengan bunyi klausul "bank berhak menghentikan proses penarikan kredit”. Rangkaian klausula tersebut pada dasarnya sejalan dengan alur bisnis perkreditan itu sendiri, dan menurut logika bisnis hal demikian itu dapat diterima sebagai sesuatu yang wajar.

d) Klausul pemberian agunan

Pencantuman klausul ini merupakan hal yang lazim bagi bank untuk lebih menjamin haknya apabila debitur wanprestasi. Dengan adanya jaminan atau agunan, terlebih dengan agunan kebendaan akan menempatkan posisi bank sebagai kreditur preference yang diutamakan posisinya dalam pengembalian hutang.

e) Klausul asuransi

Pencantuman klausul asuransi merupakan sikap antisipatif bank untuk meminimalisir potensi kerugian bank maupun nasabah debitur. Klausul ini pada umumnya terkait dengan objek jaminan, namun dapat pula ditujukan kepada pihak dalam perjanjian khususnya debitur. Dengan klausul asuransi ini potensi kerugian bank dapat diproteksi lebih optimal dibanding tidak asuransi.

\section{c. Perlindungan Hukum Dan Tanggungjawab Oleh Notaris Dalam Perjanjian Kredit Perbankan}

Hampir seluruh perjanjian kredit di bawah tangan dan perjanjian kredit notariil pada dasarnya telah dibakukan oleh pihak bank selaku kreditur. Notaris hanya melakukan penyesuaian terhadap klausul-klausul yang telah dibakukan oleh bank, sesuai dengan kondisi dan kebutuhan para pihak. Akibat dari hal ini posisi hak dan kepentingan para pihak menjadi tidak seimbang, artinya posisi debitur sebagai pihak yang membutuhkan dana menjadi lemah, dengan kata lain kepentingan bank sebagai kreditur lebih diutamakan dengan alasan bahwa bank meemberikan dana bagi debitur dan merupakan hal yang wajar dalam rangka menerapkan prinsip kehati-hatian.

Dari hasil penelitian pada BPD X, notaris sebagai pembuat akta perjanjian kredit tidak lebih dari sekedar subjek yang merupakan kepanjangan tangan dari bank, karena notaris menjalankan semua konsep perjanjian yang telah dipersiapkan oleh bank sebelumnya.

Seorang notaris harus bertindak netral dalam arti tidak memihak, bersikap jujur, dan memperhatikan segala aspek yang terkait dengan akta-akta yang dibuatnya, termasuk akibat hukum dari akta-akta yang dibuatnya dikemudian hari. Notaris harus 
memperhatikan unsur-unsur yang termuat dalam Pasal 1320 KUHPerdata dalam pembuatan semua akta-akta perjanjian termasuk akta perjanjian kredit beserta asessoirnya.

Menurut pendapat penulis terdapat beberapa hal yang dapat dilakukan seorang notaris tanpa mengurangi sikap professional dan hubungan baiknya dengan bank. Pertama, dalam UUPK sebagaimana yang telah berlaku sejak tahun 1999, maka notaris harus menjelaskan kepada pihak bank tentang ketentuan yang diatur dalam Pasal 18 UUPK dan ketentuan-ketentuan lainnya sebagaimana diatur dalam Peraturan Otoritas Jasa Keuangan.

Kedua, notaris harus menyesuaikan klausul-klausul standar yang ada dalam format perjanjian perjanjian kreditnya selama ini dengan ketentuan-ketentuan yang ada. Ketiga, memang tidak mudah untuk merubah kebijakan yang telah lama berlangsung dan hal itu telah dianggap benar, untuk melakukan penyesuaian, namun paling tidak untuk klausulklausul tertentu yang dinilai merugikan nasabah debitur seperti klausul yang menyatakan nasabah harus tunduk pada semua ketentuan bank baik ketentuan yang ada sekarang maupun perubahan peraturan yang akan ada dikemudian hari, klausul yang bahasanya sangat sulit dimengerti oleh masyarakat awam, dan klausul tentang pengalihan tanggungjawab, dan sebagainya, hal ini harus menjadi perhatian yang serius bagi para notaris dalam pembuatan akta perjanjian kredit. Dengan demikian, setidaknya notaris sudah berbuat dan melakukan peran sertanya dalam proses reformasi hukum di bidang perkreditan secara khusus dan hukum perbankan pada umumnya.

\section{PENUTUP}

\section{Kesimpulan}

Berdasarkan permasalahan dalam penulisan tesis ini, dapat disimpulkan hal-hal sebagai berikut :

a. Bentuk perlindungan hukum dari perjanjian kredit (baku/standar dan notariil) pada perjanjian kredit perbankan secara umum belum terlaksana secara maksimal meskipun terdapat ketentuan peraturan perundang-undangan yang mengatur, terkait peran notaris dalam pembuatan akta perjanjian kredit, pada dasarnya notaris memiliki peran yang sangat penting dalam menjalankan tugas dan tanggungjawabnya sebagai pejabat umum. Notaris harus berperan netral dan tidak memihak sebagaimana ketentuan pada Pasal 16 ayat 1 UUJN. Dalam proses pembuatan akta perjanjian kredit peran notaris sebagai mediator dalam hubungan 
bank dan nasabah debitur. Disatu sisi notaris harus mengamankan kepentingan perbankan dari kemungkinan kesalahan dan kerugian bank, dan disisi lain notaris juga harus memperhatikan dan memberikan perlindungan hukum atas hak-hak nasabah debitur. Kedua kepentingan ini harusnya berjalan seimbang dari akta perjanjian yang dibuat. Bentuk perlindungan hukum terhadap kepentingan hak-hak yang seimbang antara debitur dan kreditur terkait perjanjian kredit (baku/standar dan notariil) pada BPD X dalam praktiknya belum memberikan hak-hak yang seimbang diantara para pihak. Terdapat klausul-klausul perjanjian kredit baik dibawah tangan maupun notarial yang memiliki persoalan, seperti banyak sekali terdapat pengalihan tanggungjawab dan tindakan sepihak yang dirumuskan di dalam setiap klausul perjanjian kredit. Hal ini bertentangan dengan asas keseimbangan yang diatur pada UUPK. Dalam konteks perjanjian baku/standar dan notariil, hampir semua dari ketiga jenis perjanjian kredit pada BPD X yang diuraikan di atas dalam perjanjian baku/standar yang dibuat antara bank/notaris dengan nasabah debitur belum memberikan posisi yang seimbang di antara kedua belah pihak. Hal ini karena seluruh klausul telah dipersiapkan bank secara sepihak dan tidak dapat dilakukan perubahan untuk mengakomodasi kehendak debitur.

\section{Saran}

Dari permasalahan penelitian ini, terdapat beberapa saran yang penulis berikan sebagai berikut :

a. Notaris sebagai pejabat umum harus berpegang kepada aturan undang-undang dan kode etik notaris, dan notaris harus mempertahankan kemandiriannya secara profesional artinya notaris tidak boleh berpihak kepada salah satu pihak khususnya pada bank. Notaris harus memperhatikan prinsip-prinsip keseimbangan, keadilan dan kepastian hukum dalam pembuatan akta perjanjian kredit dan asessoirnya antara bank dan nasabah debitur.

b. Hubungan hukum antara bank, notaris nasabah debitur dalam proses pembuatan perjanjian kredit pada BPD $\mathrm{X}$ merupakan hubungan yang bersifat perdata, konsensual dan terbuka, maka seharusnya bank berpegang pada aturan undangundang secara konsisten. BPD X sebagai pelaku usaha juga harus memperhatikan asas-asas hukum yang terdapat dalam aturan hukum perikatan dalam pembuatan perjanjian serta memperhatikan asas yang tercantum pada Pasal 2 UUPK yang berdasarkan manfaat, keadilan, keseimbangan, keamanan dan keselamatan serta kepastian hukum. Ketidakseimbangan hak dan kewajiban atau pemaksaan 
pemberlakuan klausul-klausul yang tidak adil dan merugikan debitur dalam perjanjian kredit, dan jika terjadi sengketa hukum antara kedua belah pihak dikemudian hari hal ini dapat dibatalkan hakim pengadilan sebagai akibat dari cacat hukum.

\section{DAFTAR PUSTAKA}

\section{Buku}

Soemitro, Roni Hanitijo. Metodologi Penelitian Hukum dan Jarimetri. Jakarta: Ghalia Indonesia, 1998.

Raharjo, Satjipto. Ilmu Hukum. Bandung: PT. Citra Aditya Bakti, 2000.

\section{Jurnal}

Mariah Kamelia, Anis Mashdurohatun. "Peran Notaris Dalam Pembuatan Akta Perjanjian Kredit Dalam Perspektif Hukum Positif dan Hukum Islam.” Jurnal Akta Magister Kenotariatan UNISSULA (2017).

Putu Devi Yustisia, dkk. "Kedudukan Hukum Grosse Akta Pengakuan Hutang Notariil Dalam Pemberian Kredit Perbankan." Jurnal Magister Kenotariatan Universitas Udayana (2018).

\section{Peraturan Undang-Undang}

Indonesia. Undang-Undang Republik Indonesia tentang Perlindungan Konsumen UU No. 8 Tahun 1999.

- Undang-Undang Republik Indonesia tentang Perubahan Atas UndangUndang Nomor 30 Tahun 2004 tentang Jabatan Notaris, UU No. 2 Tahun 2014. 